\title{
PENGARUH KUALITAS PELAYANAN DAN LOKASI TERHADAP KEPUASAN PASIEN PUSKESMAS LANGSA LAMA
}

\author{
Rahmi Meutia 1)*, Puti Andiny 2)* \\ 1) Fakultas Ekonomi, Universitas Samudra \\ Email: rahmi.meutia@unsam.ac.id \\ Email: putiandiny@unsam.ac.id
}

\begin{abstract}
Penelitian ini dilakukan bertujuan untuk mengetahui pengaruh kualitas pelayanan yang terdiri dari bukti fisik (tangible), reliabilitas (reliability), daya tanggap (responsiveness), jaminan (assurance), dan empati (empaty) serta lokasi terhadap kepuasan pasien di Puskesmas Langsa Lama. Penelitian menggunakan sampel sebanyak 96 responden. Metode analisis data menggunakan persamaanregresi linier berganda, uji hipotesis (uji t dan uji F) serta koefisien determinasi $\left(\mathrm{R}^{2}\right)$. Hasil penelitian diperoleh $\mathrm{Y}=1,017+0,182 \mathrm{X} 1+0,224 \mathrm{X} 2+0,019 \mathrm{X} 3+$ $0,172 \mathrm{X} 4+0,186 \mathrm{X} 5+0,125 \mathrm{X} 6$. Konstanta sebesar 1,017 adalah kepuasan pasien sebelum dipengaruhi oleh kualitas pelayanan yang terdiri dari bukti fisik (tangible), reliabilitas (reliability), daya tanggap (responsiveness), jaminan (assurance), dan empati (empaty) serta lokasi. Kemudian koefisien bukti fisik (tangible), reliabilitas (reliability), daya tanggap (responsiveness), jaminan (assurance), dan empati (empaty) serta lokasi memberikan pengaruh positif terhadap kepuasan pasien. Hasil uji t variabel bukti fisik (tangible), jaminan (assurance) dan empati (emphaty) dapat dinyatakan berpengaruh signifikan terhadap kepuasan pasien. Sedangkan variabel reliabilitas (reliability), dayatanggap (responsiveness) dan lokasi secara parsial berpengaruh tidak signifikan terhadap kepuasan pasien. Hasil uji F diperoleh bukti fisik (tangible), reliabilitas (reliability), daya tanggap (responsiveness), jaminan (assurance), dan empati (empaty) serta lokasi secara simultan berpengaruh signifikan terhadap kepuasan pasien di Puskesmas Langsa Lama. Hasil uji koefisien determinasi $\left(\mathrm{R}^{2}\right)$ sebesar 62,6\% variabel bukti fisik (tangible), reliabilitas (reliability), daya tanggap (responsiveness), jaminan (assurance), dan empati (empaty) serta lokasi mempengaruhi kepuasan pasien di Puskesmas Langsa Lama. Sisanya sebesar $37,4 \%$ dipengaruhi oleh variabel lain yang tidak diteliti.
\end{abstract}

Keywords: kualitas layanan, lokasi, kepuasan 


\section{PENDAHULUAN}

\section{Latar Belakang Penelitian}

Kesehatan merupakan suatu kebutuhan yang mendasar bagi masyarakat. Kebutuhan tersebut yang menjadikan masyarakat merasa perlu untuk menjaga kesehatan dan memperoleh pelayanan kesehatan. Pada era globalisasi ini masyarakat semakin sadar akan kualitas atas mutu pelayanan kesehatan yang mampu memberikan kepuasan kepada masyarakat. Masyarakat mengharapkan pelayanan kesehatan yag lebih berorientasi pada kepuasan demi memenuhi kebutuhan dasar masyarakat. Kesehatan yang berkualitas akan mampu meningkatkan usia harapan hidup, menurunkan tingkat kematian serta meningkatkan produktivitas.

Pemerintah

menyelenggarakan pelayanan kesehatan mulai dari pelayanan kesehatan ditingkat desa yaitu Poli klinik Desa (Polindes) kemudian di tingkat Kecamatan Pusat Kesehatan Masyarakat (Puskesmas), serta pengembangan pelayanan Pusat Kesehatan Masyarakat saat ini sudah ada yang mencakup pelayanan kesehatan rawat jalan dan rawat inap. Kemudian bila pasien yang tidak dapat tertangani di Pusat Kesehatan Masyarakat akan dirujuk ke Rumah Sakit ditingkat Kabupaten dan Kota yang memiliki pelayanan dengan pelayanan sub spesialis.

Puskesmas sebagai pusat pelayanan kesehatan merupakan salah satu pelayanan publik ditingkat Kecamatan. Menurut Keputusan Menteri Kesehatan RI No. 128 Tahun 2004 tentang kebijakan dasar puskesmas bahwa puskesmas adalah unit pelaksana teknis Dinas Kesehatan Kabupaten/Kota yang bertanggungjawab dalam menyelenggarakan pelayanan kesehatan tingkat pertama secara menyeluruh, terpadu dan berkesinambungan.

Puskesmas sebagai ujung tombak pelayanan kesehatan perlu mendapatkan perhatian utama yang berkaitan dengan kualitas pelayanan. Sehingga puskesmas selalu dituntut untuk meningkatkan profesionalisme dari para pegawai dan meningkatkan fasilitas atau sarana kesehatan untuk memberikan kepuasan kepada masyarakat pengguna jasa kesehatan. Terciptanya kualitas pelayanan akan menciptakan kepuasan terhadap pengguna layanan. Kualitas pelayanan dapat memberikan manfaat yaitu terjalinnya hubungan harmonis antara petugas puskesmas dengan pasien.

Kualitas pelayanan merupakan salah satu faktor penting yang mempengaruhi untuk tercapainya kepuasan pasien. Kualitas pelayanan merupakan konsep pengukuran kualitas pelayanan yang terdiri dari lima dimensi bukti fisik (tangible), reliabilitas (reliability), daya tanggap (responsiveness), jaminan (assurance) dan empati (empaty) (Subagyo, 2010:244). Kelima dimensi tersebut merupakan kunci utama untuk meningkatkan kepuasan pasien. Pasien akan merasa puas jika harapannya sama atau melebihi dari apa yag dirasakan. Namun sebaliknya, pasien akan merasa tidak puas jika yang diharapkan berbeda dengan apa yag diperoleh. Selain kualitas pelayanan yang menjadi harapan dari setiap pasien adalah tempat atau lokasi dari pengobatan (Puskesmas).

Menurut Utami (2010:90), lokasi merupakan faktor yang sangat penting dalam bauran pemasaran. Pada lokasi yang tepat, sebuah usaha lebih sukses dibandingkan dengan usaha lainnya yang berlokasi kurang strategis, meskipun keduanya menjual produk yang sama dan sama-sama memiliki manajemen yang bagus. Dengan demikian, maka lokasi Puskesmas harus strategis yang mudah untuk dikunjungi oleh masyarakat sebagai pasien dari Puskesmas tersebut. Puskesmas merupakan organisasi dari pemerintah yang memberikan pelayanan kesehatan bagi masyarakat disetiap Kecamatan. Puskesmas memberikan pelayanan kesehatan bagi pasien tidak hanya rawat jalan tetapi juga memberikan rawat inap. Kota Langsa yang memiliki 5 kecamatan dan memiliki 5 Puskesmas dan salah satunya adalah Puskesmas Langsa Lama. 


\section{TINJAUAN PUSTAKA}

\section{Pengertian Kualitas Pelayanan}

Ratminto dan Atik (2010:2), pelayanan adalah produk-produk yang tidak kasat mata yang melibatkan usaha-usaha manusia dan menggunakan peralatan. Selanjutnya Arief (2011:118) menyatakan kualitas pelayanan sebagai tingkat kesempurnaan yang diharapkan dan pengandalian akan kesempurnaan tersebut untuk memenuhi keinginan pelanggan.

Menurut Wisnalmawati (2010:155) kualitas pelayanan adalahtingkat keunggulan yang diharapkan dan pengendalian atas tingkat keunggulan untukmemenuhi keinginan pelanggan. Apabila jasa yang diterima sesuai dengan yang diharapkan, maka kualitas jasa dipersepsikan baik dan memuaskan. Jika jasa yang diterima melampaui harapan pelanggan, maka kualitas jasa dipersepsikan ideal.

\section{Dimensi Kualitas Pelayanan}

Menurut Tjiptono (2008:95), menyebutkan lima dimensi dalam kualitas pelayanan, yang terdiri dari:

1. Kehandalan (reability), berkaitan dengan kemampuan perusahaan untuk menyampaikan layanan yang dijanjikan secara akurat sejak pertama kali.

2. Daya tanggap (responsiveness), berkenaan dengan kesediaan dan kemampuan penyediaan layanan untuk membantu para pelanggan dan merespon permintaan mereka dengan segera.

3. Jaminan (assurance), berkenaan dengan pengetahuan dan kesopanan karyawan serta kemampuan mereka dalam menumbuhkan rasa percaya (trust) dan keyakinan pelanggan (confidence).

4. Empati (empathy), berarti bahwa perusahaan memahami masalah para pelanggannya dan bertindak demi kepentingan pelanggan, serta memberikan perhatian personal kepada para pelanggan dan memiliki jam operasi yang nyaman.

5. Bukti fisik (tangibles), berkenaan dengan penampilan fisik fasilitas layanan, peralatan/perlengkapan, sumber daya
NIAGAWAN Vol 8 No 2 Juli 2019

manusia, dan materi komunikasi perusahaan.

Menurut Subagyo (2010:244) terdapat lima dimensi kualitas pelayanan yang biasa dikenal dengan rater, kelima elemen kunci itu adalah sebagai berikut:

1. Bukti fisik (Tangible)

Yaitu meliputi fasilitas fisik, perlengkapan, pegawai dan sarana komunikasi.indikatornya mencakup:

a. Peralatan dan fasilitas yang lengkap dan nyaman

b. Gedung/kantor yang memadai dan nyaman

c. Profil petugas yang ramah dan rapih

2. Reliabilitas (reliability)

Yaitu kemampuan memberikan layanan yang dijanjikan dengan segera, akurat, kehandalan, memuaskan. dan indikatornya mencakup:

a. Ketepatan pelaksanaan layanan

b. Kesesuai pelaksanaan dengan prosedur

c. Konsisten tidak pilih kasih

3. Daya tanggap (responsiveness)

Yaitu keinginan para staf untuk membantu para nasabah/pelanggan dan memberikan pelayanan dengan tanggap. Indikator meliputi:
a. Kecekatan petugas
b. Hemat waktu dan
c. Hemat tenaga

4. Jaminan (Assurance)

Mencakup pengetahuan, kemampuan, kesopanan dan sifat yang dapat dipercaya yang dimiliki oleh para staf/karyawan (bebas dari bahaya resiko dan keraguan), indikatornya mencakup:
a. Kemampuan petugas
b. Keramahan petugas
c. Kepercayaan pelanggan
d. Keamanan pelanggan

5. Empati (emphaty)

Yaitu meliputi kemudahan dalam melakukan hubungan komunikasi yang baik, perhatian pribadi, dan memahami kebutuhan para pelanggan.indikatornya mencakup: 
a. Kemudahan dalam memperoleh layanan

b. Kejelasan informasi

c. Pemahaman pelanggan

\section{Strategi Layanan dalam Meningkatkan Kualitas Pelayanan}

Hasan (2010:136) menyatakan bahwa untuk meningkatkan kualitas layanan dapat menggunakan strategi layanan 7-P yaitu:

1. Process

a. Rincian standar prosedur operas, manual dan deskripsi kerja

b. Prosedur solusi masalah/komplain nasabah

c. Standar kerja layanan (manusia dan teknologi)

d. Keterlibatan interfungsional

e. Tingkat just in time delivery-lead times deliveries

\section{Product}

a. Pengembangan variasi produk

b. Spesifikasi kualitas

c. Model/tampilan/ukuran kemasan kartu manual/kartu EFT

d. Logo, merek dagang, dan persepsi nasabah/publik

e. Layanan pendukung dan komplementer

f. Model layanan: full service, sell service

3. Price
a. Analisis kompetitif
b. Penetapan tingkat harga, perubahan harga, target pasar
c. Potongan provisi, hadiah, kebijakan penjualan
d. Metode/cara/sistem kredit

4. Place-chanel
a. Rencana saluran
b. Manajemen saluran, alokasi penempatan produk
c. Derajat integrasi saluran
d. Kebijakan standar (tingkat) layanan
e. Kenyamanan, keamanan (lokasi) dan fasilitas

\section{Promotion}

a. Periklanan: anggaran, target pasar, media yang digunakan, jadwal waktu tayang dan lain-lain

b. Penjualan
NIAGAWAN Vol 8 No 2 Juli 2019

c. Market share, posisi produk di pasar

d. Brand position

6. Physical evidence

a. Tampilan gedung, tata ruang dan tata letak fasiltias layanan

b. Penerangan, dekorasi dan kebersihan

c. Counter layanan transaksi manual dan automatic

d. Daya tarik, kenyamanan, kemudahan akses dan tempat parkir

7. participants

a. pelatihan skill interaksi dan resolusi masalah nasabah

b. sistem dan prosedur imbal jasa untuk mobilitas kerja

c. prosedur partisipasi team layanan dan eksekusi layanan

d. keterikatan norma-norma religius dan norma objektif universal

\section{Faktor-faktor Dalam Meningkatkan} Kualitas Pelayanan

Menurut Tjiptono (2008:99), faktorfaktor yang perlu diperhatikan dalam meningkatkan kualitas pelayanan diantaranya:

1. Mengidentifikasi determinan utama kualitas pelayanan

2. Mengelola ekspektasi (harapan) pelanggan

3. Mengelola bukti kualitas pelayanan

4. Mendidik konsumen tentang pelayanan

5. Menumbuh kembangkan budaya kualitas

6. Menciptakan automating quality

7. Menindaklanjuti pelayanan

8. Mengembangkan sistem informasi kualitas pelayanan

\section{Pengertian Lokasi}

Menurut Utami (2010:90) lokasi merupakan faktor yang sangat penting dalam bauran pemasaran. Pada lokasi yang tepat, sebuah usaha lebih sukses dibandingkan usaha lainnya yang berlokasi kurang strategis, meskipun keduanya menjual produk yang sama, dan sama-sama punya manajemen yang bagus.

Menurut Kotler (2009:82), lokasi dapat diartikan sebagai segala hal yang menunjukkan pada berbagai kegiatan yang dilakukan perusahaan untuk membuat produk 
dapat diperoleh dan tersedia bagi pelanggan sasaran.

Fahmi (2012:32), mengatakan bahwa lokasi adalah posisi keberadaan suatu aktivitas usaha ditempat yang sesuai dengan ruang lingkup bentuk bisnis tersebut. Kemudian lokasi mencerminkan fungsi kemudahan akses dan kedekatan jarak dengan sarana dan fasilitas. Menurut Lupiyoadi (2009:42), lokasi berhubungan dengan dimana perusahaan harus bermarkas dan melakukan operasi atau kegiatannya.

\section{Indikator Lokasi}

Menurut Tiptono (2008:41) lokasi dapat diukur dengan menggunakan indikator:

1. Akses yaitu kemudahan untuk sampai kelokasi dan dapat dijangkau oleh konsumen dengan transportasi

2. Tempat parkir luas dan aman berupa adanya tempat kendaraan serta kendaraan aman saat diparkirkan

3. Ekspansi berupa tempat usaha yang luas dan memiliki potensi untuk berkembang

4. Lingkungan berupa kondisi sekitar tempat usaha yang mendukung dan tidak mengganggu keamanan.

\section{Pengertian Kepuasan}

Menurut Rangkuti (2009:20) kepuasan pelanggan merupakan respon pelanggan terhadap ketidaksesuaian antara tingkat kepentingan sebelumnya dan kinerja aktual yang dirasakannya setelah pemakaian. Menurut Hartono (2010:45) kepuasan pasien adalah suatu keadaan yang dirasakan oleh seorang (klien/pasien) setelah ia mengalami suatu tindakan atau hasil dari tindakan yang memenuhi harapan-harapannya. Pelayanan kesehatan disebut bermutu apabila pelayanan tersebut dapat memberikan kepuasan bagi pasien dan merujuk pada kesembuhan penyakit serta keamanan tindakan yang diterima pasien.

\section{Manfaat Kepuasan}

Menurut Tjiptono (2012:310), kepuasan pelanggan telah menjelma menjadi kewajiban bagi setiap organisasi bisnis, peneliti pemasaran, eksekutif bisnis, bahkan politisi.
Kualitas jasa yang unggul dan konsisten dapat menumbuhkan kepuasan konsumen dan akan memberikan berbagai manfaat seperti:

1. Berdampak positif pada loyalitas pelanggan

2. Berpotensi menjadi sumber pendapatan masa depan (terutama melalui pembelian ulang, cross-selling, dan up-selling).

3. Menekan biaya transaksi pelanggan di masa depan (terutama biaya-biaya komunikasi pemasaran, penjualan, dam layanan pelanggan).

4. Menekan volatilitas dan risiko berkenaan dengan prediksi aliran kas masa depan.

5. Meningkatkan toleransi harga (terutama kesediaan pelanggan untuk membayar harga premium dan pelanggan cenderung tidak mudah tergoda untuk beralih pemasok).

6. Rekomendasi gethok tular positif.

7. Pelanggan cenderung lebih reseptif terhadap product-line extensions, brand extensions, dan new add-on services yang ditawarkan perusahaan.

8. Meningkatkan jaringan pemasok, mitra bisnis, dan saluran distribusi

\section{Indikator untuk Mengukur Kepuasan}

Menurut Hartono (2010:46), kepuasan klien ada empat indikator yaitu:

1. Melihat indikator hasil pelayanan.

2. Menampung keluhan dan saran.

3. Menyelenggarakan panel pasien/klien.

4. Menyelenggarakan survey kepuasan pasien.

\section{Hipotesis}

1. Diduga kualitas pelayanan yang terdiri dari bukti fisik (tangible), reliabilitas (reliability), daya tanggap (responsiveness), jaminan (assurance), empati (empaty) dan lokasi secara parsial berpengaruh signifikan terhadap kepuasan pasien pada Puskesmas Langsa Lama.

2. Diduga kualitas pelayanan yang terdiri dari bukti fisik (tangible), reliabilitas (reliability), daya tanggap (responsiveness), jaminan (assurance), empati (empaty) dan lokasi secara simultan berpengaruh signifikan terhadap kepuasan pasien pada Puskesmas Langsa Lama. 


\section{METODE PENELITIAN}

\section{Populasi dan Sampel}

Populasi dalam penelitian ini adalah pasien pada Puskesmas Langsa Lama yang jumlahnya tidak diketahui secara pasti. Tehnik pengambilan sampel menggunakan non probability sampling. Pertimbangan pengambilan sampel dalam penelitian ini adalah pasien yang mengunjungi Puskesmas Langsa Lama minimal 2 kali dan berusia 17 tahun atau lebih. Karena besarnya populasi tidak diketahui dengan pasti, maka penetapan jumlah sampel menggunakan rumus unknownpopulation. Dengan demikian jumlah sampel yang akan diteliti adalah sebesar 96 responden.

\section{Metode Pengumpulan Data}

1. Studi Lapangan (Field Research)

a. Observasi (Pengamatan) yaitu suatu bentuk penelitian yang dilakukan peneliti dengan pengamatan secara langsung terhadap fenomena yang terjadi pada objek penelitian.

b. Wawancara. Wawancara dalam penelitian ini dilakukan dengan cara melakukan wawancara secara terstruktur terhadap pihak-pihak yang berhubungan dengan penelitian yaitu pimpinan dan pegawai pada Puskesmas Langsa Lama.

c. Kuisioner (angket) yaitu suatu cara pengumpulan data dengan memberikan atau menyebarkan daftar pernyataan kepada responden dengan harapan mereka akan memberikan respon atas daftar pernyataan tersebut. Dalam penelitian ini daftar pernyataan diajukan kepada pasien di Puskesmas Langsa Lama

2. Penelitian Kepustakaan (Library Research). Penelitian kepustakaan dilakukan dengan cara mengumpulkan berbagai sumber bacaan.

\section{Metode Analisis Data}

Untuk mengetahui pengaruh kualitas pelayanan dan lokasi terhadap kepuasan pasien digunakan peralatan analisis yaitu persamaan regresi linier berganda yang diformulasikan sebagai berikut:

$$
\begin{aligned}
Y= & a+b_{1} X_{1}+b_{2} X_{2}+b_{3} X_{3}+b_{4} X_{4}+b_{5} X_{5}+ \\
& b_{6} X_{6}
\end{aligned}
$$

Keterangan:

$\mathrm{Y} \quad=$ kepuasan pasien

a $\quad=$ konstanta

$\mathrm{b}_{1}, \mathrm{~b}_{2}=$ koefisien regresi

$\mathrm{X}_{1} \quad=$ bukti fisik (tangible)

$\mathrm{X}_{2} \quad=$ reliabilitas (reliability)

$\mathrm{X}_{3} \quad=$ daya tanggap (responsiveness)

$\mathrm{X}_{4} \quad=$ jaminan (assurance)

$\mathrm{X}_{5} \quad=$ empati (empaty)

$\mathrm{X}_{6} \quad=$ lokasi

Uji hipotesis dalam penelitian ini dilakukan dengan menggunakan:

1. Uji t (parsial)

2. Uji F (simultan)

3. Koefisien determinasi $\left(\mathrm{R}^{2}\right)$

\section{HASIL DAN PEMBAHASAN}

Pembahasan

Pengaruh Kualitas Pelayanan dan Lokasi terhadap Kepuasan Pasien pada Puskesmas Langsa Lama

Pengaruh kualitas pelayanan dan lokasi terhadap kepuasan pasien pada Puskesmas Langsa Lama diketahui dari hasil penelitian yang dianalisis dengan menggunakan persamaan regresi linier berganda. Perhitungan menggunakan program statistik SPSS versi 20,0 dengan hasil sebagai berikut: 
Tabel 2. Coefficients

\begin{tabular}{|l|r|r|r|r|r|}
\hline \multirow{2}{*}{ Model } & \multicolumn{2}{|c|}{$\begin{array}{c}\text { Unstandardized } \\
\text { Coefficients }\end{array}$} & $\begin{array}{c}\text { Standardized } \\
\text { Coefficients }\end{array}$ & \multirow{2}{*}{$\mathrm{t}$} & \multirow{2}{*}{ Sig. } \\
\cline { 2 - 5 } & \multicolumn{1}{c|}{$\mathrm{B}$} & Std. Error & Beta & \\
\hline (Constant) & 1,017 & 1,486 &, 684 &, 495 \\
Bukti Fisik/Tangible &, 182 &, 086 &, 175 & 2,108 &, 038 \\
Reliabilitas/Reliability &, 224 &, 282 &, 226 &, 795 &, 429 \\
Daya Tanggap/Responsivenes &, 019 &, 087 &, 022 &, 218 &, 828 \\
Jaminan/Assurance &, 172 &, 051 &, 246 & 3,353 &, 001 \\
Empati/Emphaty &, 186 &, 092 &, 213 & 2,015 &, 047 \\
Lokasi &, 125 &, 254 &, 127 &, 490 &, 625 \\
\hline
\end{tabular}

a. Dependent Variable: Kepuasan Pasien

Berdasarkan tabel diatas dapat dibuat persamaan regresi linier berganda:

$\mathrm{Y}=1,017+0,182 \mathrm{X}_{1}+0,224 \mathrm{X}_{2}+0,019 \mathrm{X}_{3}+$ $0,172 \mathrm{X}_{4}+0,186 \mathrm{X}_{5}+0,125 \mathrm{X}_{6}$

Hasil persamaan regresi linier berganda dapat dijelaskan sebagai berikut:

1. Konstanta sebesar 1,017 adalah kepuasan pasien sebelum dipengaruhi oleh kualitas pelayanan yang terdiri dari bukti fisik (tangible), reliabilitas (reliability), daya tanggap (responsiveness), jaminan (assurance), dan empati (empaty) serta lokasi.

2. Koefisien regresi bukti fisik (tangible) sebesar 0,182 dan bertanda positif, menunjukkan bahwa apabila terjadi perubahan kenaikan satu satuan pada variabel bukti fisik (tangible) akan meningkatkan kepuasan pasien pada Puskesmas Langsa Lama sebesar 0,182.

3. Koefisien regresi reliabilitas (reliability) sebesar 0,224 dan bertanda positif, menunjukkan bahwa apabila terjadi perubahan kenaikan satu satuan pada variabel reliabilitas (reliability) akan meningkatkan kepuasan pasien pada Puskesmas Langsa Lama sebesar 0,224.

4. Koefisien regresi daya tanggap (responsiveness) sebesar 0,019 dan bertanda positif, menunjukkan bahwa apabila terjadi perubahan kenaikan satu satuan pada variabel daya tanggap (responsiveness) akan meningkatkan kepuasan pasien pada Puskesmas Langsa
Lama sebesar 0,019.

5. Koefisien regresi jaminan (assurance) sebesar 0,172 dan bertanda positif, menunjukkan bahwa apabila terjadi perubahan kenaikan satu satuan pada variabel jaminan (assurance) akan meningkatkan kepuasan pasien pada Puskesmas Langsa Lama sebesar 0,172.

6. Koefisien regresi empati (empaty) sebesar 0,186 dan bertanda positif, menunjukkan bahwa apabila terjadi perubahan kenaikan satu satuan pada variabel empati (empaty) akan meningkatkan kepuasan pasien pada Puskesmas Langsa Lama sebesar 0,186.

7. Koefisien regresi lokasi sebesar 0,125 dan bertanda positif, menunjukkan bahwa apabila terjadi perubahan kenaikan satu satuan pada variabel lokasi akan meningkatkan kepuasan pasien pada Puskesmas Langsa Lama sebesar 0,125.

\section{Pembuktian Hipotesis}

Pembuktian hipotesis dengan menggunakan uji $t$, uji $F$ serta uji koefisien determinasi $\left(\mathrm{R}^{2}\right)$ sebagai berikut:

1. Hasil uji secara parsial (uji t)

a. Variabel bukti fisik (tangible) $\mathrm{t} \operatorname{sig}<\alpha$ $5 \%(0,038<0,05)$, maka dapat dinyatakan bahwa bukti fisik (tangible) berpengaruh signifikan terhadap kepuasan pasien di Puskesmas Langsa Lama.

b. Variabel reliabilitas (reliability) t sig $>\alpha$ $5 \%(0,429>0,05)$, maka dapat dinyatakan bahwa reliabilitas (reliability) berpengaruh tidak signifikan terhadap 
kepuasan pasien di Puskesmas Langsa Lama. Dengan demikian hipotesis penelitian ini ditolak.

c. Variabel daya tanggap (responsiveness) $\mathrm{t}$ sig $>\alpha 5 \%(0,828>0,05)$, maka dapat dinyatakan bahwa variabel daya tanggap (responsiveness) berpengaruh tidak signifikan terhadap kepuasan pasien di Puskesmas Langsa Lama. Dengan demikian hipotesis dalam penelitian ini ditolak.

d. Variabel jaminan (assurance) $\mathrm{t} \operatorname{sig}<\alpha$ $5 \%(0,001<0,05)$, maka dapat dinyatakan bahwa jaminan (assurance) berpengaruh signifikan terhadap kepuasan pasien di Puskesmas Langsa Lama. Dengan demikian hipotesis dalam penelitian ini dapat diterima. e. Variabel empati (emphaty) t sig $<\alpha 5 \%$ $(0,047<0,05)$, maka dapat dinyatakan bahwa empati (emphaty) berpengaruh signifikan terhadap kepuasan pasien di Puskesmas Langsa Lama. Dengan demikian hipotesis dalam penelitian ini dapat diterima.

f. Variabel lokasi t sig $>\alpha 5 \%(0,625>$ 0,05), maka dapat dinyatakan bahwa lokasi berpengaruh tidak signifikan terhadap kepuasan pasien di Puskesmas Langsa Lama. Dengan demikian hipotesis dalam penelitian ini ditolak.

2. Hasil uji secara simultan (uji F)

Hasil uji secara simultan dapat diketahui dari perbandingan nilai $\mathrm{F}$ signifikan (Fsig) dan nilai $\alpha 5 \%$.

Tabel 3. Anova

\begin{tabular}{|c|c|c|c|c|c|}
\hline Model & Sum of Squares & $\mathrm{df}$ & Mean Square & $\mathrm{F}$ & Sig. \\
\hline Regression & 748,828 & 6 & 124,805 & 27,516 &, $000^{\mathrm{b}}$ \\
\hline Residual & 403,672 & 89 & 4,536 & & \\
\hline Total & 1152,500 & 95 & & & \\
\hline
\end{tabular}

a. Dependent Variable: Kepuasan Pasien

Berdasarkan tabel 3 diketahui nilai $\mathrm{F}$ sig 0,000 . Dengan demikian F sig $<\alpha 5 \%(0,000<$ $0,05)$ dapat dinyatakan bukti fisik (tangible), reliabilitas (reliability), daya tanggap (responsiveness), jaminan (assurance), dan empati (empaty) serta lokasisecara simultan berpengaruh signifikan terhadap kepuasan pasien di Puskesmas Langsa Lama dan hipotesis kedua dapat diterima.

3. Hasil uji koefisien determinasi $\left(\mathrm{R}^{2}\right)$

Hasil uji koefisien determinasi $\left(\mathrm{R}^{2}\right)$ diketahui pada tabel model summary sebagai berikut:

Tabel 4. Model Summary

\begin{tabular}{|c|c|c|c|c|}
\hline $\begin{array}{c}\text { Mode } \\
1\end{array}$ & $\mathrm{R}$ & $\begin{array}{c}\mathrm{R} \\
\text { Squar } \\
\mathrm{e}\end{array}$ & $\begin{array}{c}\text { Adjusted } \\
\text { R Square }\end{array}$ & $\begin{array}{c}\text { Std. } \\
\text { Error of } \\
\text { the } \\
\text { Estimate }\end{array}$ \\
\hline 1 &, $806^{\mathrm{a}}$ &, 650 &, 626 & 2,12970 \\
\hline
\end{tabular}

a. Predictors: (Constant), Lokasi,
Berdasarkan tabel 4 dapat diketahui nilai koefisien determinasi $\left(\mathrm{R}^{2}\right)$ menggunakan adjusted $R$ square sebesar 0,626 atau sebesar $62,6 \%$ variabel bukti fisik (tangible), reliabilitas (reliability), daya tanggap (responsiveness), jaminan (assurance), dan empati (empaty) serta lokasi mempengaruhi kepuasan pasien di Puskesmas Langsa Lama. Sisanya sebesar $37,4 \%$ dipengaruhi oleh variabel lain yang tidak diteliti emosi dan harga.

\section{KESIMPULAN DAN SARAN}

\section{Kesimpulan}

Berdasarkan pembahasan diatas maka dapat ditarik kesimpulan bahwa (1) hasil persamaan menunjukkan bahwa kualitas pelayanan yang terdiri dari bukti fisik (tangible), reliabilitas (reliability), daya tanggap (responsiveness), jaminan (assurance), dan empati (empaty) serta lokasi memberikan pengaruh positif terhadap 
kepuasan pasien pada Puskesmas Langsa Lama. (2) Hasil uji t menunjukkan bahwa bukti fisik (tangible), jaminan (assurance), dan empati (empaty) secara parsial berpengaruh signifikan terhadap kepuasan pasien di Puskesmas Langsa Lama, sedangkan variabel reliabilitas (reliability), daya tanggap (responsiveness), dan lokasi berpengaruh tidak signifikan terhadap kepuasan pasien di Puskesmas Langsa Lama. (3) Hasil uji F menunjukkan secara simultan kualitas pelayanan yang terdiri dari bukti fisik (tangible), reliabilitas (reliability), daya tanggap (responsiveness), jaminan (assurance), dan empati (empaty) serta lokasi berpengaruh signifikan terhadap kepuasan pasien di Puskesmas Langsa Lama. (4) Hasil uji koefisien determinasi $62,6 \%$ variabel kualitas pelayanan yang terdiri dari bukti fisik (tangible), reliabilitas (reliability), daya tanggap (responsiveness), jaminan (assurance), dan empati (empaty) serta lokasi mempengaruhi kepuasan pasien di Puskesmas Langsa Lama.

\section{Saran}

Berdasarkan kesimpulan diatas, maka dapat saran untuk penelitian ini adalah (1) Reliabilitas perlu perbaikan sehigga kepuasan pasien dapat meningkat melalui pelaksanaan pelayanan harus sesuai dengan harapan pasien dan pelayanan kesehatan yang tepat waktu. (2) Pihak Puskesmas dapat menyarankan kepada pemerintah Kota Langsa untuk menyediakan transportasi umum yang murah menuju ke Puskesmas Langsa Lama. (3) Bagi peneliti selanjutnya hendak menambah variabel variabel lain yang tidak digunkan dalam penelitian ini.

\section{REFERENSI}

Arief, 2011, Pemasaran Jasa dan Kualitas Pelayanan, Malang: Banyumedia Publishing.

Fahmi, Irham, 2012, Manajemen Pemasaran, Bandung: Alfabeta
p-ISSN : 2301-7775

e-ISSN : 2579-8014

NIAGAWAN Vol 8 No 2 Juli 2019

Ferdinand, Augusty, 2008, Pedoman Penelitian untuk Skripsi dan Tesis, Semarang: Badan Penerbit Universitas Diponegoro.

Hartono, Bambang, 2010, Manajemen Pemasaran untuk Rumah Sakit, Jakarta: Rineka Cipta.

Hasan, Ali, 2010, Marketing, Jakarta: Media Presindo.

Kotler, Philip, 2009, Manajemen Pemasaran, Jakarta: PT. Prehalindo.

Kotler, Philip dan Kevin Lane Keller, 2009, Manajemen Pemasaran, Jakarta: PT Indeks.

Lupiyoadi, Rambat, 2009, Manajemen Pemasaran Jasa, Jakarta: Salemba Empat.

Rangkuty, Freddy, 2009, Strategi Meningkatkan Kepuasan Pelanggan, Jakarta: Gramedia Pustaka Utama.

Ratminto dan Atik Septi Winarsih, 2010, Manajemen Pelayanan, Yogyakarta: Pustaka Pelajar.

Subagyo, Ahmad, 2010, Marketing in Business, Jakarta: Mitra Wacana Media.

Sugiyono, 2011, Statistik Untuk Penelitian, Bandung:Alfabeta

Supranto, J, 2010,Pengukuran Kepuasan Pelanggan, Jakarta: Rineka Cipta.

Tjiptono, Fandy, 2008, Strategi Pemasaran,Yogyakarta: Andi.

Gregorius, Chandra dan Dadi Adriana, 2008, Pemasaran Strategik, Yogyakarta: Penerbit Andi.

Utami, Christina Widya, 2010, Manajemen Ritel, Jakarta: Salemba Empat.

Wisnalmawati, 2010, Dimensi Kualitas Pelayanan terhadap Keputusan Pembelian, Jurnal Ekonomi dan Bisnis, No. 3, Vol.10 Hal 100-111 